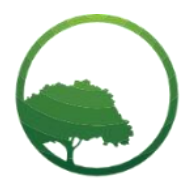

Research in Business \& Social Science

IJRBS VOL 10 NO 4 ISSN: 2147-4478

\title{
Systematic risk and performance of stock market in Kenya
}

\author{
(D)Nathan Mwenda Mutwiri(a)* (D) Job Omagwa ${ }^{(b)}$ (iD) Lucy Wamugo ${ }^{(c)}$ \\ (a) PhD., Lecturer, Kenyatta University, School of Business, PO BOX 43844-00100, Nairobi Kenya \\ ${ }^{(b, c)}$ Ph.D., School of Business Kenyatta University, P O Box 43844-00100, Nairobi Kenya
}

\author{
A R T I CLE INFO \\ Article history: \\ Received 07 May 2021 \\ Received in rev. form 23 May 2021 \\ Accepted 27 May 2021 \\ Keywords: \\ 91 treasury bills rate, Inflation, \\ systematic risk, stock performance. \\ JEL Classification: \\ G00; G13
}

\begin{abstract}
A B S T R A C T
Stock prices in Kenya have been experiencing drastic volatility over the years. In the year 2015 alone, the value of the listed companies shrunk by about 2.5 billion USD, representing about $25 \%$ of the national government annual budget. The performance of the stock market is an important proxy of a country's economic environment. Rational investors constantly value and revise their portfolio composition so as to maximize their wealth. Whereas effectively diversified portfolio minimizes the unsystematic risk, systematic risks cannot be managed by simple diversification. Investors, therefore, need to understand the effect of these systematic risks on the stock performance. The study sought to determine the relationship between systematic risk factors using Inflation and interest rates and the performance of the stock market in Kenya. The study adopted a positivist philosophy and employed a correlation research design. The study targeted all the stock listed in the Nairobi Securities exchange. The study was underpinned by the Efficient Market Hypothesis, Arbitrage Pricing theory, and used integration analysis to establish the relationships between the variables of the study. The study found a significant long-run positive relationship between interest rate, inflation, and performance of the stock market in Kenya. Investment firms, the financial analyst should use past data on 91 Treasury bills rate and Inflation, to predict the future performance of stock exchange for the benefit of investors.
\end{abstract}

(C) 2021 by the authors. Licensee SSBFNET, Istanbul, Turkey. This article is an open access article distributed under the terms and conditions of the Creative Commons Attribution (CC BY) license (http://creativecommons.org/licenses/by/4.0/).

\section{Introduction}

Performance of a stock market is important element in any financial market and economy (Kitati, Evusa, \& Maithya, 2015). This is because the stock market plays a critical role in providing alternatives investment opportunities for both local and international participants in any economy. Investors invest in the stock market with an aim of increasing their wealth or generate positive returns without necessarily increasing their risk to greater magnitudes (Apiyeva, 2007). Most investors believe they can outperform the market by generating higher returns than the markets (Erdugan, 2012). Investments involve risk and uncertainty and capital market helps in managing risk and uncertainty. When the stocks markets operate smoothly and efficiently, they facilitate economic growth and lower production costs and business risk. This in the long run promotes growth of GDP and growth of employment (Handa, 2005).

Excessive volatility of stock prices in the financial markets, affects the smooth operations of financial markets and consequently adversely affects the performance of any economy (Wang \& Huang, 2012). In 1929 the Wall Street crash, October 191987 black Monday and the Asian crisis in 1997 and most recently the Global financial crisis of 2008 represents some of examples of how stock markets have affected significantly the economies of the countries and their trading blocks. Financial analysts, are concerned with understanding the factors that affect the persistent fluctuations of stock prices. This is of importance in analyzing market trends and making investments that are well diversified and balanced from the risk perception (Erdugan, 2012).

Over the years, the operations of securities markets have continually grown with introduction of many products. This has given investors more flexibility in terms of what options they have at their disposal, this has led to more diversification in the terms of investments products as well increased the activity of the securities markets (Apiyeva, 2007). Securities markets provide liquidity

\footnotetext{
* Corresponding author. ORCID ID: 0000-0002-9158-320X

(C) 2021 by the authors. Hosting by SSBFNET. Peer review under responsibility of Center for Strategic Studies in Business and Finance. https://doi.org/10.20525/ijrbs.v10i4.1180
} 
and enable implementation of both short run and long-term projects hence assisting in development of economy. This is in addition to attracting foreign inflows, which provides adequate cash flows. Stock markets performance is a significant indicator of the performance of a country economy (Dimitrova, 2005). Progressive rise in stocks prices and active volumes of stocks traded at the countries stock exchange, are usually an indicator of sound market and business policies (Clare \& Thomas, 1994). Therefore any progressive governments, monitor the performance of the stock markets, as well as ensure that the factors that affect the performance are closely monitored.

The Nairobi stock market performance has experienced fluctuations in the last ten years under study. In the year 2015 alone, the value of listed companies shrunk by 10\% translating to about Ksh 250 Billion (Dyer \& Blair Investment Bank, 2016). In the year 2016 the stock markets shrunk by a further 259 billion. This represents about $25 \%$ of national government annual budget. In the year 2013 NSE was top in Africa and was ranked $5^{\text {th }}$ best performed stock market in the world. In this year the stock's value appreciated by rose by $43 \%$ representing about Ksh 650 Billion. The Nairobi All Share Index (NASI) fluctuated from 92 points in 2008 to 65 and 92 points in 2009 and 2010 respectively (NSE, 2010). This was followed by further decline to 83 and 82 basis points in 2011 and 2012.The Index, rose to 122 in 2013 and increased to 166 in the year 2014 before declining to 156 in 2015 and 140 points in 2016 (NSE,2017).

The dynamic behavior of stock markets is a very critical factor in any policy makers as well as financial analyst (Addo \& Sunzuoye, 2013). Globally economist, analyst and investors are interested in comprehending the factors that affect the consistent fluctuations of stock markets over time (Gatuhi, 2015). This is anchored on the fact that understanding the events which affect the volatility of stock prices is essential, in building an accurate predictive model that can forecast the future movements' patterns. This can be helpful for investors when making informed investments and diversification decisions.

Systematic risk factors are factors that affect the stock market as a whole. These factors are not unique to individual companies or stocks but they affect the entire market. Rational investors make decisions to maximize their returns given a level of risks (Erdugan, 2012). Total risk comprise of unsystematic risk and systematic risk. Systematic risks present to investors a challenge because they cannot be hedged out by diversification (Patra \& Poshakwale, 2006). Therefore investors need to understand how the shocks in these systematic factors relate with the stock prices so that they can react or predict possible stock prices based on predicted changes in systematic risk factors. Empirical literature proves that among the important systematic risk factors include the level of interest rates and inflation rate.

The correlation between stock market performance and the systematic risks is critical to both academicians as well as those vested with policy making roles. Though important the direction of the relationships between systematic risks and stock performance, the strength and the direction has not been clearly defined both in the short run and long run. Barnor (2014) found that money supply and interest rate had negative relationship with stock returns, whereas exchange rate had a positive relationship with stock returns. Ahmed (2011) studied the relationship between selected macroeconomic variables and concluded that money supply, GDP and price level had a positive relationship with stock returns. Nguyen (2016) found that the predictability of stock prices was more accurate using previous systematic shocks as opposed to previous price volatility indicating that past systematic risk movements can predict future stock prices than past data on stock itself.

In Kenya the stock market is regulated by the Nairobi Securities exchange which is the principal bourse of Kenya (NSE, 2015). The NSE was established in 1954 and has undergone several transformation and development over the years (NSE, 2016).The Capital Markets Authority of Kenya is an independent public agency established by Act of Parliament, Cap 485 A and is charged with the primary responsibility of regulating activities of the stock exchange, market intermediaries and the central depository system. Its main role is mobilizing and allocation of capital resources to finance productive investments (CMA, 2017).

Systematic risks are risk which affect the entire market (Kazi, 2004). These risk are not diversifiable within a particular market. Systematic risks include factors which contribute to un-diversifiable risks in financial market (Barnor, 2014). These risk factors cannot be eliminated or reduced by diversification of portfolio holding within a certain market. This is because they are inherent in all securities in a certain market (Granger, Yang, \& Huang, 2000). Investors know that they cannot avert this type of risk by simply holding many different securities. Systematic risk factors affect the whole market and are usually beyond the influence of individual companies (Erdugan, 2012). Systematic risk factors include changes in the Treasury bill rate and Inflation rate.

Patra and Poshakwale (2006) explains that, whereas the treasury bills rate may not represent the actual opportunity cost of borrowing, it is an important factor in determining the influence of level of interest on the direction of the stock prices. This is because both personal and institutional investors participate in the open market operations and their activity is influenced by the level of interest rates (Addo \& Sunzuoye, 2013). If the Treasury bill rate is higher, being a risk free rate then investors may prefer holding a big portion of their assets in Treasury bills. This is achieved by disposing securities held, in preference of acquiring more treasury bills. The level of 91Treasury bill rate in 2008 was about $7.5 \%$, this rose to about $16.20 \%$ in the year 2011 and further rose to $10.36 \%$ by the year 2012.There rate rose to $11.4 \%$ in 2014 but dropped to between $8.16 \%$ and $11.49 \%$ in 2015 . The Treasury bill rate in year 2016 ranged between $7.89 \%$ and $8.61 \%$ (CBK, 2017).

Inflation is the general rise in price levels (Mishkin, 2011). In periods of inflation there is a general increase in the amount of money in supply enabling investors to have more money to offer for goods. Varga (2005) indicates that inflation rates affect the intrinsic 
value of stock prices and as a consequence, their desirability based of investors wealth maximization. Shocks in Inflation are correlated with the movements of stock prices because inflation rate has an effect on the expected real return of investors

The national and international role of most securities markets is to provide an avenue for investors and firms to share risk and rewards (Erdugan, 2012). The security market aids in flow of funds from investors to productive sectors which aid in creating national wealth, improving employment levels as well as economic stability (Kazi, 2004). Securities markets provide opportunities for investors to trade in equities, debt securities as well as derivatives. Markets act as a critical conduit of overseas flow of equity investments in most economies, therefore connecting a nation to the global economy (Tursoy, Gunsel, \& Rjoub, 2008). Investors analyse the stock markets based on the movements in price level, and their ease of liquidity trade off which is offered at the securities markets. If the markets are bullish i.e. when they are active, on upward trends, confident of the securities markets operations investors are more willing to participate in the NSE because it's an investment vehicle as well as mechanism for liquidity trade off. When the market is bearish, the prices are falling and this dooms the hope that the stocks will regain an upward trend at least in the short term. This is characterized by most investors selling the stock so as to exit the market before the prices fall further (Patra \& Poshakwale, 2006).

Stock market performance can be measured by aggregating the total companies' stock market performance (Dobbs \& Koller, 2005). This is done by calculating the total returns to shareholders (TRS). TRS is defined as the appreciation in share price plus dividend yield over the period of consideration. The limitation of TRS, as a measure of stock market performance is that it is a short term measure, and may be misleading as stocks cannot consistently report high total returns to shareholders. The use of stock indices to track stock exchange market performance has received wide acceptance in the finance field. Both domestic and international investors, use average indexes as a proxy to determine the direction of future stock performance. S \&Poor, FTSE and NYSE are among globally accepted indices that gives an indication of the stock market performance. The official index in the Kenya is the Nairobi All share index and the NSE 20 Share Index (CMA, 2016)

Nairobi Securities Exchange (NSE) is the principal bourse in Kenya, offering an automated platform for the listing and trading of multiple securities. The NSE was established in 1954, when it was registered in societies act, as a voluntary association of stockbrokers and charged with the responsibility of developing securities markets and regulating trading activities (NSE, 2016). The market has undergone various transformations over the years, in tandem with the developing business and market. The NSE is regulated by the Capital market authority (CMA, 2011).CMA role is to ensure that there is sound regulatory frameworks, and counter checks the performance of the NSE to ensure prudent an fair practices in the securities trading (Mwaniki, 2015)

The stock market in Kenya is relatively developed in the African Context. It is ranked second in Africa after Johannesburg markets in South Africa. The performance of NSE over the years since its inception has been cyclical. The performance of shares has been fluctuating, leaving the investors unable to accurately predict or make forecasts of expected returns (Barnor, 2014). NSE had progressively increased the value of the investors in some periods increasing the speculative aspect of the market, but in other periods the returns have been whipped by bearish markets leaving investors in panic.

The NSE 20 share index has exhibited volatility over the years. In 2007 NSE 20 index basis points were 5,262 this declined to 4,522 in 2008 and further declined to 3,027 in the year 2009 (Dyer and Blair Invetsment Bank, 2016). The year 2010 saw a $40 \%$ increase in the basis points to 4,257. However in the subsequent year, it declined by about $12 \%$ to 3,751 basis points and 3,735 in year the 2012.The year 2013 saw the Index improve by $28 \%$ to reach 4,788 and a marginal rise in 2014 saw the basis points get to 5,017 (NSE, 2015). In year 2015, there was a reduction in the performance of the NSE which led to the reduction in the basis points to 4,618 which represented a decline of about $10 \%$ from the year 2015. In the last year under the study i.e. year 2016, there was a big decline in the value of shares translating to about $23 \%$ basis points of 3,555 (NSE, 2017).

Empirical evidence across the world indicates contradicting results in regard to factors affecting the stock performance. Khalid (2017) studied the relationship between interest rates and stock markets, by focusing on the longrun relationships between short term interest rates and found a positive long run relationship between interest rates and stock prices. Nguyen ( 2016) found a negative relationship, between interest rates and stock prices. Muhammand and Rasheed (2001) studied the shortrun and long run relationship between the exchange rate and stock prices and found no relationship between exchange rate and the stock prices. Humpe (2008), Apiyeva (2007) and Kuwornu( 2012) found that Interest rates, exchange rate, Inflation and Gross domestic product have a significant relationship with the performance of stock market. The studies document contradictory findings in regard to the direction of relationship of these variables and stock performance, some reporting negative relationship while others document a positive relationship

There is substantial empirical evidence on Inflation, Interest rates, and stock performance ( Phuyal (2016), Kitati, Evusa and Maithya (2015) and Gatuhi( 2015)).These studies adopted regression models to analyse data. This methodology is deficient to the extent that of data on systematic risks (being time series in nature), evolves over time due to the long run relationships making it mostly non stationary (Ifionu \& Ibe, 2015). Whereas regression can be used when the data is de-trended to correct the non stationarity, doing so would lead to loss of variable interrelationships. This means that the findings of these studies including Gatuhi are potentially misleading. This study adopted Vector autoregressive models which take care of non- stationarity of the variables without losing the valuable relationships. In addition the VAR model allows the study to determine relationship between lagged and present stock performance 
This paper aims to determine the relationship between interest rates changes and performance of the stock market in Kenya. The study also examines the relationship between Inflation rate changes and performance of the stock market in Kenya.

The study sought to test the following null hypotheses:

Ho1: Interest rates changes have no significant relationship with performance of stock market in Kenya.

$\boldsymbol{H}_{02}$ : Inflation changes have no significant relationship with performance of the stock market in Kenya.

\section{Literature review}

\section{Theoretical Review}

Efficient Market Theory was put forward by (Fama, 1970). Fama argues that the primary role of any market is allocation of ownership of the economy's capital stock. He opined that an ideal market would provide accurate signals of resource allocation. He explained than in a market, firms make production and investments decisions and investors chose securities that represent ownership of firms. Apiyeva (2007) utilized the theory and argued that a market which the securities price fully reflect all available information is an efficient market. Jensen (1968) opines that it is impossible to beat the market. This implies that an investor cannot make abnormal profits by trading in the stock markets. Tursoy, Gunsel, and Rjoub (2008) indicates that stock prices follow a random walk and it is therefore not possible to accurately predict prices based on the past trends. The theories categorizes markets based on their efficiency and brings out three forms of market efficiency. The weak form of market is a level of efficiency which prices reflect all past information that is available. Therefore, investors cannot beat the market by analyzing historical information of stocks.

The semi strong efficiency is the level of efficiency at which the prices in the stock prices reflect past and present information that is publicly available. This level is concerned more with the speed of adjustments of information to the stock market prices (Fama, 1970). The third and most advanced level off efficiency is the strong form of efficiency, in this level the stocks market prices meet the conditions of both weak and semi strong and addition requirements that the stock prices reflect future information (Handa, 2005). In this level of efficiency, there is no insider trading and the internal managers of the firm do not have vital information on future investments decisions that will enable them make more returns than the average market returns.

In the context of this study, the Nairobi stock exchange is assumed to be in the second level of efficiency, the semi strong efficiency. Nguyen, Nhan and Bach (2013) findings indicates that markets in the developing countries have developed past the weak form to the semi strong form. The level of efficiency was equally adopted by Gatuhi (2015). In this level the analysis, the focus is on the speed of adjustments of prices to the new information arriving in the market. This study aims at establishing the speed and magnitude of speed of reaction of stocks to the systematic risks.

Arbitrage Pricing Theory was promulgated by Ross (1976) and is an extension of the Capital Asset Pricing Model (CAPM). This theory has been very instrumental in asset pricing because, unlike CAPM which suggested that asset prices are determined by one single common factor, Arbitrage Pricing theory advocates that shares prices are driven by many factors (Kazi, 2004). The APT theory was mainly developed due to the dissatisfaction of CAPM and was fronted as an alternative to pricing of assets. CAPM having been derived from the first principles of expected utility theory. Ross (1976) indicates that the assumptions underlying expected utility theory made no use of common variability. APT is a factor model which includes multiple factors, that represent the fundamental risk in asset returns. The model being a multi factor allows an asset to have several measures of systematic risk. Each of the measure captures the important sensitivity of an asset to a specific factor.

Multifactor asset pricing models are based on APT and they evaluate a multifactor equilibrium in scenarios where there are many sources of risk other than the market factor (Erdugan, 2012).This reasoning is consistent with modern financial theory which has focused with systematic effects as the most likely sources of risk affecting a portfolio performance. APT opines that returns on securities are linearly related to small number k-systematic factors rather than a single factor. APT does not stipulate what the kfactors are. This has been left open for researchers to use as many factors as possible, based on the uniqueness of the markets that they are studying.

Ross( 1976) explained that APT incorporates multiple factors that represent the fundamental risk in asset returns. The model being a multi factor allows an asset to have several measures of systematic risks which are represented by macro-economic variables in the determination of asset price. Each of the measure captures the important sensitivity of an asset to a specific factor. This model has been widely accepted because it allows researchers to capture most systematic risk variables such as the level of interest rate, inflation rate, exchange rate and gross domestic product in the prediction of stocks prices. Majority of the studies on APT employed the methodology suggested by Roll and Ross (1980). Roll and Ross first estimated the expected returns and the factor coefficients on assets returns from time series data. They then used the estimates obtained in the first step to test cross section pricing conclusion on APT.

Nawalkha (2007) investigated the validity of APT .The study explained that on the onset, most researchers were very skeptical on the theory as they believed that APT offered too much for little. The major concern was the random process of identifying the factors. The study introduced a new concept of a well-diversified variable which was introduced to represent the true factors. Kazi (2004) applied the theory using a ten year data on NYSE listed companies. By using the maximum likelihood factor analysis, they determined 
the number of common factors and their respective sensitivity coefficients. They run a cross section linear regression and got the risk premium for each factor. Their findings indicated that about $50 \%$ chance that the five factors identified were significant and that three to four factors explained the variations of the stock returns in the two markets. This study applied the APT theory which opines that there many factors which relate with the stock returns. The study used the theory to test the relationship between several systematic risks and the performance of stock markets in Kenya.

The Keynesian theory was developed by John Maynard Keynes (1936). Keynes's ideas referred to as Keynesianism became very influential to economic policy after great depression (Engelhardt, 2009). Keynes explained that an increase in the general price level or inflation is caused by an increase in aggregate demand which is above the aggregate supply. Keynes argues that if the economy is at full output level, an increase in government expenditure, private consumption and a rise in private investment will cause a rise aggregate demand (Reddy, 2012). The rise in aggregate demand leads to a general increase in price levels. Ifionu (2015) explains that, inflation pressure is due to the fact that at full employment of output and with maximum utilization of scarce resources, an economy cannot increase its aggregate supply to match the increasing aggregate demand.

\section{Empirical Review}

\section{Bill rate and performance of stock market}

There is empirical evidence about Keynesian propositions on the inter-relations between money supply and policy actions and interest rates for the IS-LM framework and the stock market activities (Kuwornu, 2012).Changes in Inflation levels and Money supply are intertwined and they all affect the purchasing power of investors. This has an effect on the activity on their stock markets because stocks markets acts as agents of adjusting planned consumption with the current information available. Varga (2005) explains that inflation rates affect the intrinsic value of stock prices and as a consequence their desirability based of investors wealth maximization. The theory is applied in this study context because it explains the relationship between inflation and price of commodities. Shocks in Inflation are correlated with the movements of stock prices because inflation rate has an effect on the expected real return of investors. This theory is relevant in this study because it explains that changes in consumer price index have an effect on market prices. The study assessed the correlation between changes in CPI and the stock market prices.

Nguyen (2016) analyzed the systematic risk indicators and the stock market returns in the emerging market, focusing on the Vietnam market. The study investigated the effect of interest rates using deposit rate, lending rate and refinancing rate and their relationships with Vietnam's stock market returns. Monthly data on the variables were analyzed using Vector Autoregressive (VAR) model to establish the relationships and determine the linkage between the variables and the relationship between interest rates and Vietnam stock performance. The study utilized unit root, Johansen cointegration tests, Granger causality test and impulse response function to establish both the short run and long run relationship. The findings of the study indicate that predictability of the stock market volatilities was more accurate using the previous volatility interest rates as opposed to previous volatility of its stock itself. The study found that interest had a significant positive relationship with the Vietnam stock prices. However, the study fails to consider the effects on the volumes of shares which represents demand and supply in the relationship between interest rates and stock prices. This current study included the volume of shares traded as this is important in the relationship between the systematic risk and the performance of stock exchange.

Khan, Javed, Shahzad, Sheikh, Saddique and Riaz, (2014) studied the impact of the interest rates on the performance of stocks in Pakistan. The study used monthly data from June 2007 to January 2009 and used Pearson correlation and linear regression analysis to establish the relationship between interest rates and stock performance. The study found that interest rates are strongly negatively related to stock prices. The study found that increase in the interest rates, caused a decrease in the market index over the time under study. The study fails to consider the effect of the previous period stock performance on the current performance of the stock in the present periods. This current study captured the effect of perilous performances on current stock performance by including three past lags of stock performance.

Kuwornu (2012) investigated the effect of Treasury bills rate as a proxy for interest rates on the Ghanaian stock market returns. The study utilized data over period of January 1992 to December 2008 and used macro-economic variables. The study adopted Johansen multivariate Co-integration tests which showed that interest rates are co-integrated with Ghanaian stock market performance. This indicated evidence of long run relationship between interest rates and stock performance. The study found that in the short run treasury bills rate significantly influenced the stock returns. These results showed that there is a positive relationship between interest rates and the stock prices. The study also found that about $79 \%$ of the deviations of the stock returns were found to be correlated in the short run. The study however, did not include information if volume of stocks traded. This current study included the volume as its important in determining the relationship between interest rate and stock performance.

\section{Inflation and Performance of Stock Market}

Ifionu and Ibe (2015) studied Inflation and stock prices on the Nigerian Stock exchange. The study used time series data covering a period of 12 years. The study tested the stationarity of the data using Augmented Dickey fuller (ADF) and found that all the variables were integrated at order 1(1). The study employed the cointegration, Johannsen's test and Granger Causality to test short run and long run relationships. The findings indicated that there is no causal relationship between inflation and other independent variables 
used in the study, besides inflation being found to be the important variable in explaining stock pricing prices in Nigeria.The study however used annualized data and did not report quarterly changes. The current study adopted quarterly data therefore was able to capture quarterly movements.

Shrestha and Subedi (2014) sought to establish the relationship between inflation and the stock market performance in Nepal. The study used Ordinary Least squares estimation method to examine the relationship between the two variables. The study found that performance of stock market in Nepal positively responded to changes in Inflation. The study documents that investors in stock seem to take equity as a hedge against inflation considering stock as an alternative financial instrument. The use of OLS in establishing the relationship between Inflation and stock performance has a weakness in that it does not allow the researcher to capture the effect of past stock performance on present stock performance. This weakness was addressed in this study by using Vector Autoregressive Model which has capacity to capture these relationships.

Tursoy, Gunsel and Rjoub (2008) investigated the Arbitrage price theory on the Istanbul stock exchange. The main purpose of their study was to empirically test arbitrage pricing theory in the Istanbul stock exchange. The study examined the effect of Consumer Price Index representing inflation as one of the systematic risk factors on the performance of Istanbul Stock Exchange. The study used Ordinary Least squares method to determine the relationship between the two variables. The regression results of this study found that Consumer price Index was a significant factor in determining the level of prices in the metallic manufacturing firms. The study however did not test any causality between inflation and other variables, this study tested not only the relationship between inflation and stock performance but also tested granger causality between inflation, interest rates, Foreign Exchange rate and gross domestic product.

\section{Research and Methodology}

\section{Philosophy}

This study adopted the positivism philosophy. The philosophy is considered more objective and is anchored in scientific methods in testing relationships in a study. The philosophy follows a well-defined structure which ensures that the study findings are objective and accurate. Aliyu, Bello, Kasim, and Martin (2014) contends that positivism philosophy is adopted when using observable social reality and because of the structured nature of the research and scientist approach, the results are independent of the researchers views and are widely generalizable

\section{Research design}

This study employed a correlation research design. This research design is concerned with assessment of relationship between variables. The correlation research design is based on the premise of a statistically significant relationship exist between the independent variables and the dependent variable (Saunders, Lewis, \& Thornhill, 2009). This design is appropriate for this study as the research seeks to determine the relationship between the systematic risk and the stock market performance. Kothari (2004) indicates that this design is appropriate for studies that aim at determining the strength of relationship and use the results for predictive purpose. This design was similarly used by Erdugan (2012) in establishing the effect of macro-economic variables on stock performance.

\section{Methodology}

Granger Representation Theorem (GRT) developed an effective method of analyzing non stationary data without losing long run valuable information as in the case for other methods which require differencing or de-trending techniques. This method is known as cointegration. Vector Autoregressive Models (VAR) models are used for multivariate time series. The advantage of the VAR models is that in their structures each variable is a linear function of the past lags of its itself and other variables(Humpe, 2008).The variables of choice are determined and VAR models determine the short-run adjustments is often determined by the VAR model. The number of lags is critical and must be determined prior to estimation.

The general form of a $\operatorname{VAR}_{(\mathrm{p})}$ model is describe by:

$$
Y_{t}=C+A_{i} Y_{t-1}+A_{2} Y_{t-2}+. .+A_{p} Y_{t-p}+B_{x t}+\mathrm{e}_{\mathrm{t}}
$$

Where;

$y_{t}$ is a $k \times 1$ vector variables,

$c$ is a $k \times 1$ vector of constants,

$A_{i}$ is a time-invariant $k \times k$ matrix of parameters

$e_{t}$ is a $k \times 1$ vector of error terms

Bxt is the matrix of the deterministic component (exogenous) 
$\mathrm{P}$ is the lag order

\section{Data Collection Procedure}

The researcher obtained a research authorization letter from Kenyatta University Graduate School. This in addition to the licence from the National commission for science, technology and innovation (NACOSTI) to authorize use of secondary data. Data on stock performance was obtained from published statements in Nairobi Securities Exchange website as well as from the reports submitted to the capital Market Authority. Data on the independent variables was obtained from Central Bank of Kenya and Kenya National Bureau of Statistics (KNBS)

\section{Data Analysis, Findings and Discussions}

Figure 1 below shows the trend movements between 91 Treasury Bill Rate and the NSE 20 share Index.

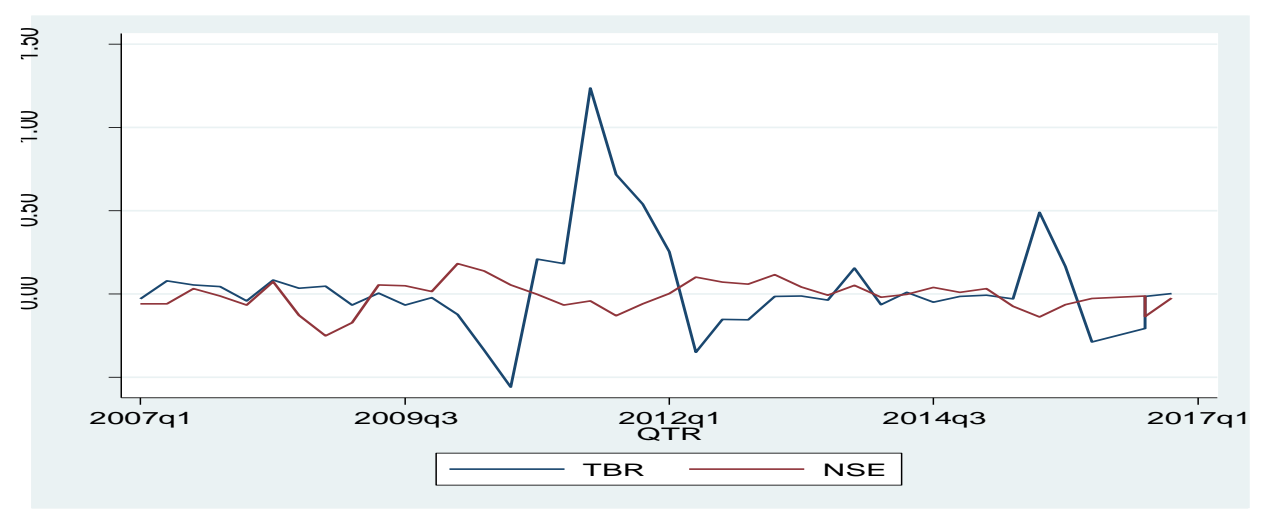

Figure 1: Trend analysis of 91treasury Bill Rate \& NSE 20 Share Index; Source: Study data (2007 - 2016)

\section{Trend analysis Inflation \& NSE 20 Share Index}

Figure 2 below shows the trend movements between Changes in Inflation rate and the NSE 20 share Index.

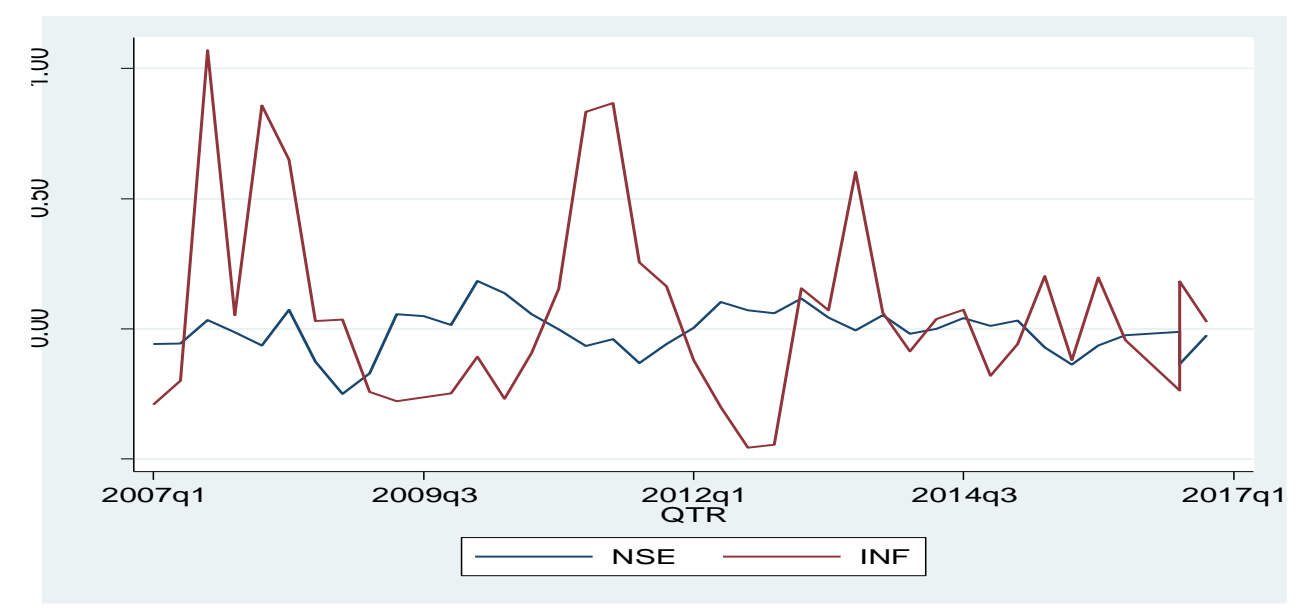

Figure 2: Trend movements between changes in inflation rate and the NSE 20 share Index Source: Study data (2007 - 2016)

Table 1: Lagrange-Multiplier Results

Lagrange-multiplier test

\begin{tabular}{|r|rrc|}
\hline lag & chi2 & df & Prob $>$ chi2 \\
\hline 1 & 42.3533 & 49 & 0.73769 \\
2 & 39.0462 & 49 & 0.84480 \\
3 & 68.9669 & 49 & 0.03149 \\
4 & 38.4137 & 49 & 0.86195 \\
\hline
\end{tabular}

HO: no autocorrelation at lag order 
Source: Study data $(2007-2016)$

The results from the table 1 above show that the $\mathrm{P}$ values at lag 4 are more than 5\% therefore we accept the null hypothesis that there is no serial correlation. This is desirable for the model because it means that there is no autocorrelation

\section{Jarque-Bera Test results}

Table 2: Jarque-Bera Test results

Jarque-Bera test
\begin{tabular}{|r|rrc|}
\hline Equation & chi2 & df & Prob > chi2 \\
\hline D_nse & 0.153 & 2 & 0.92641 \\
D_wbr & 0.696 & 2 & 0.70620 \\
D_tbr & 0.634 & 2 & 0.72839 \\
D_fex & 0.754 & 2 & 0.68597 \\
D_if1 & 0.251 & 2 & 0.88203 \\
D_gdp & 0.251 & 2 & 0.88219 \\
D_tv1 & 1.893 & 2 & 0.38815 \\
ALL & 4.631 & 14 & 0.99032 \\
\hline
\end{tabular}

Source: Study data $(2007-2016)$

The results of the Jarque-Bera test are shown above. The null hypothesis under this test is that the residuals are not significantly different from a normal distribution. Given that the p-value was greater than 0.05 significance for the residual, we failed to reject the null hypothesis and thus the conclusion that the residuals are normally distributed

91 Treasury Bill Rate and NSE 20 share Index Johansen Normalized Results

Table 3: 91 Treasury Bill Rate and NSE 20 share Index Johansen Normalized Results

\begin{tabular}{lccc}
$\begin{array}{l}\text { Cointegrating equations } \\
\text { Equation }\end{array}$ & Parms & chi2 & P>chi2 \\
\hline ce1 & 1 & 5.78608 & 0.0162 \\
\hline
\end{tabular}

Identification: beta is exactly identified

\begin{tabular}{|c|c|c|c|c|c|c|}
\hline beta & Coef. & Std. Err. & $z$ & $P>|z|$ & [95\% conf. & Interval] \\
\hline \multicolumn{7}{|l|}{ _ce1 } \\
\hline $\begin{array}{l}\text { nse } \\
\text { tbr }\end{array}$ & $\begin{array}{r}1 \\
-197.563\end{array}$ & 82.13221 & -2.41 & 0.016 & -358.5392 & -36.58688 \\
\hline _cons & -2470.254 & . & . & . & . & \\
\hline
\end{tabular}

Source: Study data $(2007-2016)$

The results of Johansen normalized shows that changes in 91 Treasury bill rate are positively related with changes in NSE 20 share Index. This finding is consisted with findings of Kuwomu (2012) but contracted (Khalid, 2017).

Inflation and NSE 20 Share Index Johansen Normalized Results

Table 4: Inflation and NSE 20 Share Index Johansen Normalized Results

cointegrating equations

\begin{tabular}{lccc} 
Equation & Parms & chi2 & P>chi2 \\
\hline -ce1 & 1 & 7.14545 & 0.0075 \\
\hline
\end{tabular}

Identification: beta is exactly identified

Johansen normalization restriction imposed

\begin{tabular}{rr|rrrrrr}
\hline & beta & Coef. & Std. Err. & $z$ & $\mathrm{P}>|z|$ & [95\% Conf. Interva1] \\
\hline _ce1 & nse & 1 & & & & & \\
& ns & & & & & & \\
if1 & -492.7363 & 184.3316 & -2.67 & 0.008 & $-854.019 \dot{6}$ & $-131.45 \dot{3}$ \\
_cons & 1164.776 &. &. &. &. &. \\
\hline
\end{tabular}

Source: Study data $(2007-2016)$ 
The table 4 indicates that there is a positive and significant relationship between Inflation and NSE 20 share index. This means that an increase in inflation levels corresponds to increase in share prices. This finding is in agreement with Ifionu and Ibe (2015) and Shrestha and Subedi (2014).

\section{Conclusions}

This study sought to establish the relationship between systematic risks and performance of Nairobi stock market. The study used NSE 20 share index as a good proxy of the entire market. This study adopted a positivist philosophy and correlation research design.

The study found a significant long run positive relationship between 91 treasury bills and the performance of Nairobi stock exchange as measured by the NSE 20 share index. This means an in increase in 91 days treasury bills correspondent to an increase in NSE 20 share Index. The study found no significant relationship for all the three lags independently. Meaning that changes in 91 Treasury bill for the previous quarters do not individually explain changes in Nairobi stock performance. Based on these findings the study concluded that previous changes in interest rates up to three quarters have a positive effect on the stock performance.

The study found that there is a positive relationship between changes in inflation and the performance of Nairobi stock market. The changes in inflation significantly explain the movements in stock performance. The study found that increase in CPI explains increase in prices of Nairobi stock exchange. In the short run only one lag of inflation was found to be significantly explaining changes in Nairobi stock performance. Hence the study concludes that changes in inflation have a positive and significant effects with the performance of the stock market in Kenya.

the study recommends that the central bank should wisely use monetary tools so as to give indication of the free risk rate of interest rate because a rise in 91 treasury rates raises the investors expectation of minimum return and this makes the price they are willing to dispose of their shares increase.

Individual investors have a lot to learn from the findings of the study. Investors usually endeavor to diversify all the risk associated with their asset portfolios. With the findings of this study, investors will be informed on how to counter the expected movements of systematic risks in the market. They will be correctly informed on when to buy or sell depending on the expected movements of systematic risk factors. The findings of this study, have shown if investors have data of previous quarterly movements of up to three quarters they can establish the expected direction of stock prices and therefore be able to earn more returns

Having established the relationship between systematic risk and performance of Nairobi stock markets, a study should be carried to establish the effect of the systematic risk on the trading volumes in the Nairobi stock market.

\section{References}

Addo, A., \& Sunzuoye, F. (2013). The impact of trasury bill rate and interest rate on the stock market returs:Case of ghana Stock Exchange. European Journal of Business and Economics , 15-24.

Ahmed, E. M. (2011). The long run relationship between money supply, real GDP, and price level:Emperical evidence from Sudan. Journal of Business studies .

Alshogeathri, M. A. (1998). Macroeconomic determinants of the stock movements: empirical evidence from the Saudi stock market. M.S king Saud University.

Andersen, T. G. (1996). Return volatility and trading volume: an information flow interpretation of stochastic volatility. Journal of finance 51, 169-204.

Apiyeva, D. (2007). The determinants of stock market performance in emerging economies: the case of Latin America and Asia pacific. June Middlesex university research repository.

Barnor, C. (2014). The effect of macroeconomic variables on stock market returns in Ghana. Walden university.

C.B.K. (2017). Www.cbk.or.ke. Retrieved 2020, from central bank of Kenya.

Central bank of Kenya. (2011). Monetary policy statement. Nairobi: central bank.

Clare, A. D., \& Thomas, S. H. (1994). Macroeconomic Factors, The APT and the UK Stock Market. Journal of Business Finance and Accounting, Vol. 21 , 309-330.

Dimitrova, D. (2005). The relationship between exchange rates and Stocks prices:Studied in a multivariate model. Issues in political economy, 14 .

Dobbs,R.,\& Koller,T.(2005).Mckinssey \& company.Retrieved may5th,2017, from mckinsey: http://www.mckinsey.com Dolado, J. J \& H., L. (1996). Making wald test work for cointergrated var systems. Econometric reviews, 15, $369-386$.

Erdugan, R. (2012). The effect of economic Factors on perfomance Of Australian Stock Market. Melbourne: Victoria University Melbourne. 
Fama, E. F. (1970). A review of theory and empirical work. Journal of finance.

Fama, E. F., \& French, k. R. (1996). Multifactor explanations of asset pricing anomalies. Journal of finance, 51(1), 5584.

Gatuhi, S. K. (2015). Macroeconomic factors and stock market performance in Kenya. Jomo Kenyatta University of agriculture and technology.

Granger, C. W., yang, \& Huang. (2000). A bivariate causality between stock price and exchange rates: evidence from recent Asian flu. The quarterly review of economics and finance, pp. 337-54.

Handa, C. (2005). Irrelevance of Open Market Operations in Some Economies with Government being Dominated in rateof return.

Ifionu, E. P., \& Ibe, r. C. (2015). Inflation, interest rates, real gross domestic product and stock prices on the Nigerian stock exchange: a post sap impact analysis. Research journal of finance and accounting,6(14) , 215-223.

Jensen, M. C. (1968). The performance of mutual funds in the period 1945-1964. Journal of finance, 23( 2), 389-416.

Johansen, S. (1988). Statistical analysis of cointegrating vectors. Journal of economic dynamics and control, 12, 23154.

Kazi, M. H. (2004). Systematic risks factors in Australian security pricing. New south wales, Australia: school of economics and finance, college of law and business, university of west Sydney.

Khalid, W. (2017). Effects of interest rate and exchange rate on the stock market performance of Pakistan: a cointegration approach. Journal of finance and economics, 5(5), 219-232.

Kitati, E., Evusa, Z., \& Maithya, H. (2015). Effect of Macroeconomic Variables on Stock Market Prices for the Companies Quoted on the Nairobi Securities Exchange in Kenya. International Journal of sciences:Basic and Apllied Reserach, 21(5), 235-265.

Kothari, C. R. (2004). Research methodology: methods and techniques. Delhi: new age international (p) ltd publishers. Mwaniki, C. (2015, May 4). Nse ranked Second Stock Exchange in Africa. Business daily

Mishkin, F. S. (2011). Monetary policy strategy. Nber working papers series.

Muhammand, N., \& Rasheed, A. (2001). Stock prices and exchange Rates: Are they related? Evidence from South asian Countries. Pakistan, Karanchi: Applied Economic Reserach Center.

Mutwiri. N.M (2017) monetary policy and inflation in kenya. International journal of academic research in accounting, finance and management sciences 7(1)

Nawalkha, S. (2007). Is the Arbitrage Pricing Theory Dead? Retrieved April 15, 2015, from SSRN: htp://ssm.com/paper=984734

Nguyen, T. T. (2016). Macroeconomic indicators and the stock market returns in emerging economies: the case of Vietnam. London: Cardiff metropolitan university.

Phuyal, N. (2016). Can microeconomic variables explain long term stock market movements? A study of Nepalis capital market. Journal of business and management research, 1 (1), 26-38.

Poi, B., \& Wiggins, V. (2001). Testing for panel-level heteroskedasticity and autocorrelation.

Retrieved from http://www.stata.com/support/faqs/stat/panel.html

Reddy, D. L. (2012). Impact on inflation and GDP on stock market returns in India. International journal of advanced research in management and social sciences, 63-81.

Ross, S. A. (1976). The arbitrage theory of capital asset pricing. Journal of economy theory.

Rotich, H., Kathanje, m., \& Maana, I. (2007). A monetary policy reaction function for Kenya. 13th annual African econometric society conference, Pretoria.

Tursoy, T., Gunsel, N., \& Rjoub, h. (2008). Macroeconomic factors, the apt and Istanbul stock market. International research of finance and economics.

Vargas, h. H. (2005). Exchange rate policy and inflation targeting in Colombia. Inter-American development bank research department working paper 539.

Venkatesan, k. (2010). Testing random walk hypothesis of Indian stock market returns: evidence from the national stock exchange (nse). Sri lanka: University of Kelaniya.

Wang, T., \& Huang, Z. (2012). The relationship between volatility and Trading Volume in the chinese stock market:a voltility decomposing perspective. Annals of Economic and Finance, 211-236 
Publisher's Note: SSBFNET stays neutral with regard to jurisdictional claims in published maps and institutional affiliations.

\section{(c) (1)}

(C) 2021 by the authors. Licensee SSBFNET, Istanbul, Turkey. This article is an open access article distributed under the terms and conditions of the Creative Commons Attribution (CC BY) license (http://creativecommons.org/licenses/by/4.0/).

International Journal of Research in Business and Social Science (2147-4478) by SSBFNET is licensed under a Creative Commons Attribution 4.0 International License. 